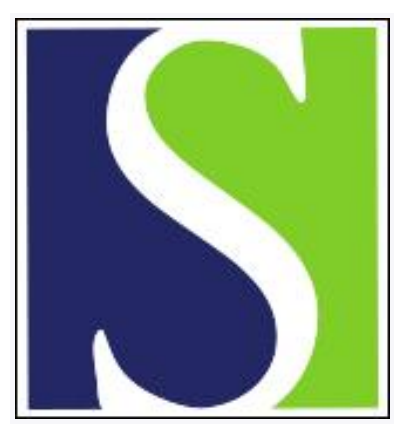

Scand J Work Environ Health 1998;24(2):145-152

https://doi.org/10.5271/sjweh.292

Issue date: Apr 1998

Occupational factors affecting sick leave attributed to low back pain

by Wickström GJ, Pentti J

The following article refers to this text: 2010;36(1):34-41

Key terms: biomechanical load; physical environment; psychosocial load; respect at work; sickness absence

This article in PubMed: www.ncbi.nlm.nih.gov/pubmed/9630063

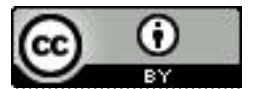




\title{
Occupational factors affecting sick leave attributed to low-back pain
}

\author{
by Gustav J Wickström, MD, ${ }^{1}$ Jaana Pentti, $\mathrm{BSc}^{1}$
}

\author{
Wickström GJ, Pentti J. Occupational factors affecting sick leave attributed to low back pain. Scand J Work Environ \\ Health 1998;24(2):145-52.
}

\begin{abstract}
Objectives The purpose of this study was to determine the occupational factors that cause workers to take sick leave attributed to low-back pain.

Methods Twice, with a 24-month interval, 117 white- and 189 blue-collar employees from 2 metal industry companies completed a questionnaire on recurrent low-back pain and exposure to potential risk factors (biomechanical loads, physical environment, psychosocial factors) at work. Sick leave was monitored for the period between the questionnaires.

Results Low-back pain was predicted by exposure to harmful biomechanical loads among both white- and blue-collar workers [odds ratio (OR) 4.1 and 4.7, respectively), stress among white-collar workers (OR 2.4), and draft among blue-collar workers (OR 2.3). The take-up of sick leave was predicted by exposure to harmful biomechanical loads [rate ratio (RR) 1.7]; for sick leaves attributed to low-back pain the rate ratio was 3.1. Lack of recognition and respect at work predicted sick leave attributed to low-back pain (RR 2.0), but not sick leave attributed to other disorders.

Conclusions Recurrent low-back pain is preceded by reports of harmful biomechanical loads at work among white- and blue-collar workers, by stress among white-collar workers and by draft among blue-collar workers. The environmental and psychosocial factors under study did not modify the relation between biomechanical loads and recurrent low-back pain. Sick leave attributed to back disorders is preceded by exposure to biomechanical loads at work and by a lack of recognition and respect at work among blue-collar workers. Biomechanical loading seems to be the most important occupational factor predicting both recurrent low-back pain and sick leave attributed to back disorders. Lack of recognition and respect at work appear to affect sick leave attributed to back disorders.
\end{abstract}

Key terms biomechanical load, psychosocial load, physical environment, respect, sickness absence.

The causes of low-back disorders have been actively sought for several decades. Initially, the main interest was in the association between mechanical loads on the lumbar spine, the capacity of its tissues to tolerate strain, and the occurrence of low-back pain $(1,2)$. As it became clear that the occurrence of low-back pain could not be explained by exposure to biomechanical factors alone, interest in other risk factors increased.

Today, the etiology of nonspecific low-back disorders is considered multifactorial. Exposure to several risk factors and the individual ability to cope with them determine whether a disorder will develop. As neither infections nor immunologic, hormonal, or toxicologic reactions have been shown to play any significant role in the development of low-back disorders, most attention is currently being paid to biomechani$\mathrm{cal}$ and psychosocial factors. No one factor alone seems sufficient to cause a disorder, if not present to an extreme degree. Nor does any factor seem absolutely necessary for the devel- opment of a disorder. With the exception of accidental injury, nearly all disorders seem to be due to the combined action of physical and psychological factors. Muscle tension seems to be an important pathway from psychosocially adverse job conditions to musculoskeletal symptoms $(3,4)$. Muscle pain may reflect a reduced capacity to cope with the environment (5).

In several cross-sectional studies, monotonous work, high perceived work load, and time pressure have been found to be related to various musculoskeletal symptoms. Lack of social support also seems to be associated with the development of musculoskeletal disorders. Several studies have indicated an association between back disorders and stress, while some have shown an association with demand or control, social support, and personality (6). In a Swedish study, the psychosocial work environment was found to be as important as physical work load for the appearance of musculoskeletal symptoms (7). In another, low social sup-

Turku Regional Institute of Occupational Health, Turku, Finland.

Reprint requests to: Professor Gustav Wickström, Turku Regional Institute of Occupational Health, Hämeenkatu 10, FIN-20500 Turku, Finland. [gustav.wickstrom@occuphealth.fi] 
port at work, as well as high job strain, was found to be associated with tenderness in the back muscles (8). In a Dutch study, based on a large sample of the working age population, the occurrence of back symptoms correlated with fast work pace, monotonous work, physically heavy work, and dirty work, but the odds ratios were low (9).

In follow-up studies carried out in Finland, problems with superiors or workmates have been found to increase the incidence of sciatic pain among men in office work (10), and poor satisfaction with the social relationships at work has been shown to precede an increase in low-back disorders in industry (11).

Low-back disorders may or may not lead to sick leave. In Finland, the increase in sick leave attributed to low-back disorders in the 1980s has leveled off and may even have turned into a slight decline (12). Civil servants with low control over their work have lately been shown to be prone to short sick leaves attributed to back pain more commonly than those with high control (13). However, the relations between the factors causing low-back pain and sick leave attributed to low-back pain are still unclear $(6,14)$.

The objective of this study was to determine the occupational factors that cause employees in the metal industry to take sick leave attributed to low-back pain.

\section{Subjects and methods}

\section{Subjects}

At the start of an intervention study and 24 months later white- and blue-collar employees from 2 companies (a shipyard and a ventilation equipment producing factory) were asked, by questionnaire, about their experience of low-back pain and about their exposure to various factors considered to be potential risk factors for low-back pain (15). Answers on both occasions were obtained from 117 white-collar employees ( $75 \%$ of those approached) and 189 blue-collar workers $(52 \%)$. They were all men. The mean age of the white-collar employees (planners) was 40 (range 24-55) years, and that of the blue-collar employees (plumbers, sheet metal workers, welders, referred to in this report as "workers") was 38 (range 18-56) years. Absence on sick leave was monitored for the 24-month period between the questionnaires.

\section{Methods}

Questionnaire. The question concerning the occurrence of low-back pain was "Have you experienced recurrent low-back pain during the last 12 months?" (no/yes).

For the physical work environment and the biomechanical loads the following question was asked: "Do you consider the following factors harmful in your work: noise, cold, draft, poor lighting, heavy lifting and carrying, pushing or pulling, awkward postures, standing, sitting?" (not present or not harmful/somewhat harmful; definitely harmful).

The psychosocial factors were asked about as follows: "To what degree can you affect your work conditions?" (not at all/to some degree; a lot). "How much recognition and respect do you receive at work?" (none at all/some; a lot). The feeling of job security was asked about with the question "How secure do you feel in your job?" (very secure; rather secure/not secure but not insecure; rather insecure; very insecure). The feeling of stress was inquired about with the question "Have you experienced stress?" (never; a few times ever; a few times during the last 5 years/several times during the last 5 years; continuous stress during the last year; continuous stress during the last 5 years).

Sick leave. Sick leave was registered by the companies. In both companies, the employees were allowed to be on paid sick leave $1-3$ days with the permission of the company's occupational health nurse, who registered the reported cause of the leave; a sick leave of more than 3 days had to be certified by a physician (the company physician or some other qualified physician), who made the diagnosis. The sick leaves were divided into 3 groups according to the following diagnoses: back disorders (ICD numbers 353, 720_722, $724,737,846,847$ ), other musculoskeletal disorders (ICD $710-739$, excluding those included under back disorders), and other disorders or diseases (all other codes) according to the International Classification of Diseases (16).

Analysis of the results. So that the responses could be grouped into only 2 classes, they were dichotomized as evenly as possible. The responses were divided according to the slashes $(/)$ in the Questionnaire section under Methods for the planners. The dichotomization was the same for the responses of the workers, with the exception of 2 questions (heavy lifting, carrying, pushing and pulling; awkward postures), which were divided so that "a lot" constituted 1 class and the rest of the responses the other.

In addition to the 4 separate questions concerning the biomechanical loads being analyzed, the questions were combined into a combined variable that was classified as "harmful" if any of the 4 basic variables was classified as harmful.

The relations of low-back pain and sick leave attributed to low-back pain to physical work environment, biomechanical loads, and psychosocial load factors were determined by logistic regression analysis. The age-adjusted odds ratios (OR) between low-back pain and its risk factors were estimated by a logistic regression model. The independent role of the risk factors that were significantly related to low-back pain was tested with a model in which all these factors were included. The modifying effect of age on the relation between low-back pain and its risk factors was determined by testing the interaction term "age $\times$ risk factor" in a logistic model. The same method was used for examining the modifying effect of psychosocial factors on the relation between low-back 
pain and biomechanical load. The analyses were made with the SAS statistical program package (17).

On the basis of the number of periods of sick leave for each employee, the rate of absenteeism per 100 person-years, as well as the age-adjusted rate ratios (RR), were calculated. As the number of spells of sick leave is a form of count data, Poisson regression models were fitted to the data. Use of the Poisson model implies that the between-employee variance in rates of sick leave is equal to the expected rate of sick leave. When rates of sick leave vary between persons (after the predictors have been taken into account) overdispersion can occur relative to that predicted from the Poisson model. When the dispersion of the periods of sick leave was greater than that predicted by the Poisson model, we used the square root of deviance divided by the degrees of freedom to adjust for the standard errors. This calculation did not affect the rate ratio estimates, but it did widen the confidence intervals. To analyze the interaction between psychosocial factors and biomechanical load, we used the cross-product term. For all the analyses we used the SAS program package (17). Poisson regression models were calculated using the GENMOD procedure (18).

\section{Results}

\section{Experience of low-back pain and exposure to risk factors}

Recurrent low-back pain was reported by nearly a third of the planners and up to half of the workers. Compared with the planners, the workers more commonly reported exposure to a harmful physical environment, biomechanical loads, and psychosocial factors. At the end of the study, the occurrence of nearly all the variables covered was reported to be higher than at the beginning (table 1).

The rate of sickness absence was 6 times higher among the workers than among the planners. Of the workers' sickness absence rate, $12 \%$ was attributed to back disorders, while the corresponding figure for the planners was $4 \%$. Most of the sick leaves attributed to back disorders lasted for more than 3 days (table 2).

\section{Associations between reported risk factors and low- back pain among planners}

Regarding the physical environment, reports of noise, cold, and draft did not correlate with the concomitant experience of recurrent low-back pain among the planners, while poor lighting did. No environmental factor predicted the occurrence of low-back pain during the following 24 months, nor did reported low-back pain predict future dissatisfaction with any environmental factor (table 3 ).

Of the biomechanical factors, reports of harmful standing, harmful sitting, and awkward postures correlated with a concomitant occurrence of low-back pain among the planners; for the combined variable the odds ratio (OR) was 3.1. Reports of biomechanical loads predicted future experience of low-back pain (when combined OR $=4.1$ ), while low-back pain only weakly predicted future reporting of harmful standing, sitting, or awkward postures (when combined $\mathrm{OR}=2.7$ ).

Regarding the psychosocial factors, low-back pain was somewhat related to a concomitant experience of stress among the planners, but not to any other factor covered by the questionnaire. Stress also predicted future experience of low-back pain, but low-back pain did not predict future reporting of stress (table 3 ).

In a model including all risk factors significantly related to low-back pain, combined biomechanical load (OR 2.87,

Table 1. Low-back pain and exposure to potential risk factors for low-back pain in the beginning and at the end of the 2-year followup.

\begin{tabular}{|c|c|c|c|c|}
\hline \multirow[t]{2}{*}{ Risk factor } & \multicolumn{2}{|c|}{$\begin{array}{c}\text { Planners } \\
(N=117)\end{array}$} & \multicolumn{2}{|c|}{$\begin{array}{c}\text { Workers } \\
(N=189)\end{array}$} \\
\hline & $\begin{array}{l}\text { Start } \\
(\%)\end{array}$ & $\begin{array}{l}\text { End } \\
(\%)\end{array}$ & $\begin{array}{c}\text { Start } \\
(\%)\end{array}$ & $\begin{array}{l}\text { End } \\
(\%)\end{array}$ \\
\hline \multicolumn{5}{|l|}{ Low-back disorders } \\
\hline Reported recurrent low-back pain & 27 & 31 & 34 & 49 \\
\hline \multicolumn{5}{|l|}{ Physical environment } \\
\hline $\begin{array}{l}\text { Noise } \\
\text { Cold } \\
\text { Draft } \\
\text { Poor lighting }\end{array}$ & $\begin{array}{l}24 \\
23 \\
45 \\
24\end{array}$ & $\begin{array}{l}30 \\
29 \\
58 \\
21\end{array}$ & $\begin{array}{l}55 \\
32 \\
47 \\
17\end{array}$ & $\begin{array}{l}57 \\
44 \\
62 \\
28\end{array}$ \\
\hline \multicolumn{5}{|l|}{ Biomechanical load } \\
\hline $\begin{array}{l}\text { Lifting, carrying, pushing, pulling } \\
\text { Awkward postures } \\
\text { Harmful standing } \\
\text { Harmful sitting }\end{array}$ & $\begin{array}{r}2 \\
14 \\
10 \\
41\end{array}$ & $\begin{array}{r}1 \\
21 \\
18 \\
46\end{array}$ & $\begin{array}{l}20 \\
51 \\
54 \\
27\end{array}$ & $\begin{array}{l}38 \\
59 \\
62 \\
29\end{array}$ \\
\hline \multicolumn{5}{|l|}{ Psychosocial factors } \\
\hline $\begin{array}{l}\text { Few possibilities to affect work } \\
\text { conditions } \\
\text { Lack of recognition and respect } \\
\text { at work } \\
\text { Job insecurity } \\
\text { Stress }\end{array}$ & $\begin{array}{l}15 \\
19 \\
59 \\
49\end{array}$ & $\begin{array}{l}16 \\
30 \\
54 \\
46\end{array}$ & $\begin{array}{l}25 \\
52 \\
68 \\
27\end{array}$ & $\begin{array}{l}28 \\
56 \\
54 \\
36\end{array}$ \\
\hline
\end{tabular}

Table 2. Sickness absence rate per 100 person-years according to diagnostic class and length of sick leave.

\begin{tabular}{lcc}
\hline Cause of sick leave & $\begin{array}{c}\text { Planners } \\
(\mathrm{N}=117)\end{array}$ & $\begin{array}{c}\text { Workers } \\
(\mathrm{N}=189)\end{array}$ \\
\hline Back disorder & 2.1 & 39.9 \\
$1-3$ days & 0.0 & 7.9 \\
$>3$ days & 2.1 & 32.0 \\
Other musculoskeletal disorder & 4.3 & 86.0 \\
$1-3$ days & 0.9 & 20.4 \\
$>3$ days & 3.4 & 65.6 \\
Other disorder & 47.9 & 201.3 \\
$1-3$ days & 36.3 & 148.1 \\
$>3$ days & 11.5 & 53.2 \\
Total & 54.3 & 327.2 \\
$1-3$ days & 37.2 & 176.5 \\
$>3$ days & 17.1 & 150.8 \\
\hline
\end{tabular}


Table 3. Age-adjusted odds ratios (OR) and their $95 \%$ confidence intervals ( $95 \% \mathrm{CI}$ ) between recurrent low-back pain and risk factors for low-back pain among planners $(N=117)$. $(R 1$ and $R 2=$ risk factors at start and end, respectively; $L B P 1$ and $L B P 2=$ recurrent lowback pain at start and end, respectively)

\begin{tabular}{|c|c|c|c|c|c|c|}
\hline \multirow[t]{2}{*}{ Risk factor } & \multicolumn{2}{|c|}{$\mathrm{R} 1 \leftrightarrow$ LBP1 } & \multicolumn{2}{|c|}{$\mathrm{R} 1 \leftrightarrow \mathrm{LBP} 2$} & \multicolumn{2}{|c|}{ LBP1 $\leftrightarrow \mathrm{R} 2$} \\
\hline & OR & $95 \% \mathrm{Cl}$ & $\mathrm{OR}$ & $95 \% \mathrm{Cl}$ & OR & $95 \% \mathrm{Cl}$ \\
\hline \multicolumn{7}{|l|}{ Physical environment } \\
\hline $\begin{array}{l}\text { Noise } \\
\text { Cold } \\
\text { Draft } \\
\text { Poor lighting }\end{array}$ & $\begin{array}{l}1.08 \\
0.50 \\
0.82 \\
3.21\end{array}$ & $\begin{array}{l}0.41-2.83 \\
0.17-1.48 \\
0.34-1.96 \\
1.23-8.35\end{array}$ & $\begin{array}{l}1.83 \\
0.75 \\
1.27 \\
2.13\end{array}$ & $\begin{array}{l}0.73-4.58 \\
0.28-2.02 \\
0.55-2.93 \\
0.83-5.47\end{array}$ & $\begin{array}{l}1.03 \\
1.04 \\
1.84 \\
1.24\end{array}$ & $\begin{array}{l}0.42-2.53 \\
0.41-2.61 \\
0.74-4.53 \\
0.45-3.43\end{array}$ \\
\hline Biomechanical load & 3.11 & $1.29-7.52$ & 4.08 & $1.70-9.80$ & 2.74 & $1.07-6.98$ \\
\hline $\begin{array}{l}\text { Lifting, carrying, pushing, pulling } \\
\text { Awkward postures } \\
\text { Harmful standing } \\
\text { Harmful sitting }\end{array}$ & $\begin{array}{l}4 . \overline{05} \\
6.67 \\
2.41\end{array}$ & $\begin{array}{l}1.28-12.76 \\
1.79-24.84 \\
1.03-5.61\end{array}$ & $\begin{array}{l}6 . \overline{19} \\
5.28 \\
2.82\end{array}$ & $\begin{array}{l}1.90-20.16 \\
1.44-19.42 \\
1.23-6.44\end{array}$ & $\begin{array}{l}2 . \overline{58} \\
1.87 \\
2.02\end{array}$ & $\begin{array}{l}0.97-6.85 \\
0.68-5.19 \\
0.86-4.74\end{array}$ \\
\hline \multicolumn{7}{|l|}{ Psychosocial factors } \\
\hline $\begin{array}{l}\text { Few possibilities to affect work conditions } \\
\text { Lack of recognition and respect at work } \\
\text { Job insecurity } \\
\text { Stress }\end{array}$ & $\begin{array}{l}0.88 \\
1.13 \\
1.72 \\
2.48\end{array}$ & $\begin{array}{l}0.26-3.02 \\
0.39-3.30 \\
0.72-4.12 \\
1.05-5.88\end{array}$ & $\begin{array}{l}0.71 \\
1.00 \\
1.33 \\
2.42\end{array}$ & $\begin{array}{l}0.21-2.39 \\
0.34-2.90 \\
0.58-3.03 \\
1.06-5.56\end{array}$ & $\begin{array}{l}1.89 \\
1.81 \\
1.41 \\
1.13\end{array}$ & $\begin{array}{l}0.65-5.50 \\
0.74-4.40 \\
0.60-3.32 \\
0.49-2.61\end{array}$ \\
\hline
\end{tabular}

95\% CI $1.14-7.21$ ), poor lighting (OR $3.02,95 \%$ CI $1.11-$ 8.20 ), and stress (OR 2.37,95\% CI 0.96-5.88) showed a significant independent or almost significant independent relation to concomitant low-back pain for the planners, while combined biomechanical load showed a significant independent relation (OR 3.85, 95\% CI 1.58-9.41) and stress an almost significant independent relation (OR $2.32,95 \% \mathrm{CI}$ 0.98 -5.52) to future reporting of recurrent low-back pain.

\section{Associations between reported risk factors and low- back pain among the workers}

Among the workers, reports of exposure to draft were related to a simultaneous experience of low-back pain. Reporting draft predicted future experience of low-back pain, and lowback pain predicted future reporting of draft (table 4).
As to biomechanical loads, low-back pain was related to harmful lifting, standing, sitting and awkward postures (when combined, $\mathrm{OR}=6.83,95 \%$ CI $2.50-18.7$ ) among the workers. The last 3 predicted future experience of low-back pain (when combined, $\mathrm{OR}=4.70,95 \%$ CI 2.13-10.4), while low-back pain predicted future reporting of exposure to harmful standing.

Of the psychosocial factors, few possibilities to affect work conditions was related to concomitant low-back pain among the workers. Stress predicted future low-back pain only among those over 40 years of age (OR $13.3,95 \%$ CI 1.46-109). Low-back pain predicted future reporting of few possibilities to affect work conditions (OR 2.2).

In a model including all risk factors significantly related to low-back pain, combined biomechanical load showed an independent relation both to concomitant (OR 5.76,95\% CI

Table 4. Age-adjusted odds ratios (OR) and their $95 \%$ confidence intervals (95\% Cl) between recurrent low-back pain and risk factors for low-back pain among workers $(N=189)$. $(R 1$ and $R 2=$ risk factors at start and end, respectively; LBP1 and LBP2 = recurrent lowback pain at start and end, respectively)

\begin{tabular}{|c|c|c|c|c|c|c|}
\hline \multirow[t]{2}{*}{ Risk factor } & \multicolumn{2}{|c|}{$\mathrm{R} 1 \leftrightarrow \mathrm{LBP} 1$} & \multicolumn{2}{|c|}{$\mathrm{R} 1 \leftrightarrow$ LBP2 } & \multicolumn{2}{|c|}{ LBP1 $\leftrightarrow R 2$} \\
\hline & $\mathrm{OR}$ & $95 \% \mathrm{Cl}$ & OR & $95 \% \mathrm{Cl}$ & $\mathrm{OR}$ & $95 \% \mathrm{Cl}$ \\
\hline \multicolumn{7}{|l|}{ Physical environment } \\
\hline $\begin{array}{l}\text { Noise } \\
\text { Cold } \\
\text { Draft } \\
\text { Poor lighting }\end{array}$ & $\begin{array}{l}1.10 \\
1.46 \\
2.06 \\
1.07\end{array}$ & $\begin{array}{l}0.59-2.04 \\
0.76-2.80 \\
1.11-3.84 \\
0.46-2.48\end{array}$ & $\begin{array}{l}1.09 \\
1.69 \\
2.30 \\
0.95\end{array}$ & $\begin{array}{l}0.60-1.98 \\
0.89-3.23 \\
1.25-4.22 \\
0.43-2.12\end{array}$ & $\begin{array}{l}1.27 \\
1.58 \\
2.00 \\
1.45\end{array}$ & $\begin{array}{l}0.68-2.39 \\
0.85-2.93 \\
1.02-3.90 \\
0.74-2.85\end{array}$ \\
\hline Biomechanical load & 6.83 & $2.50-18.67$ & 4.70 & $2.13-10.38$ & 2.51 & $0.90-6.99$ \\
\hline $\begin{array}{l}\text { Lifting, carrying, pushing, pulling } \\
\text { Awkward postures } \\
\text { Harmful standing } \\
\text { Harmful sitting }\end{array}$ & $\begin{array}{l}2.82 \\
1.95 \\
2.48 \\
2.68\end{array}$ & $\begin{array}{l}1.32-6.02 \\
1.04-3.69 \\
1.30-4.72 \\
1.36-5.27\end{array}$ & $\begin{array}{l}1.18 \\
2.80 \\
2.49 \\
3.67\end{array}$ & $\begin{array}{l}0.56-2.49 \\
1.49-5.28 \\
1.35-4.61 \\
1.77-7.62\end{array}$ & $\begin{array}{l}1.73 \\
0.88 \\
2.06 \\
1.89\end{array}$ & $\begin{array}{l}0.92-3.24 \\
0.47-1.64 \\
1.06-4.01 \\
0.97-3.67\end{array}$ \\
\hline \multicolumn{7}{|l|}{ Psychosocial factors } \\
\hline $\begin{array}{l}\text { Few possibilities to affect work conditions } \\
\text { Lack of recognition and respect at work } \\
\text { Job insecurity } \\
\text { Stress }\end{array}$ & $\begin{array}{l}2.30 \\
1.28 \\
0.66 \\
1.72\end{array}$ & $\begin{array}{l}1.16-4.55 \\
0.69-2.37 \\
0.34-1.25 \\
0.88-3.39\end{array}$ & $\begin{array}{l}1.89 \\
1.30 \\
1.05 \\
1.59\end{array}$ & $\begin{array}{l}0.99-3.83 \\
0.71-2.36 \\
0.56-1.99 \\
0.81-3.11\end{array}$ & $\begin{array}{l}2.22 \\
1.20 \\
0.89 \\
1.58\end{array}$ & $\begin{array}{l}1.14-4.33 \\
0.64-2.25 \\
0.48-1.64 \\
0.83-2.99\end{array}$ \\
\hline
\end{tabular}


2.03-16.4) and to future (OR 3.90, 95\% CI 1.72-8.87) low-back pain among the workers, while exposure to draft and possibilities to affect work conditions did not.

Among the workers who did not experience recurrent back pain during the previous 12 months at the beginning of the study, only reported exposure to harmful biomechanical loads predicted reporting back pain 2 years later (OR for planners $6.85,95 \%$ CI 1.32-35.6; OR for workers 2.67 , $95 \%$ CI $1.02-6.94)$.

Neither among the planners nor among the workers was any psychosocial factor found to modify the relation between biomechanical load and back pain.

\section{Rate of worker sick leave}

Sick leave attributed to back disorder was predicted by reports of exposure to cold (RR 1.8), combined biomechanical load (RR 3.1), awkward postures (RR 1.7), and lack of recognition and respect at work (RR 2.0). Sick leave attributed to other musculoskeletal disorders was predicted by draft (RR 1.7), combined biomechanical load (RR 2.0), lifting, carrying, pushing, pulling (RR 2.0), awkward postures (RR 2.0), and stress (RR 1.6). Sick leave attributed to other disorders was predicted by cold (RR 1.5), draft (RR 1.5), and awkward postures (RR 1.6) (table 5).

In a model including all risk factors significantly related to sick leave attributed to back pain, combined biomechanical loads (RR 2.58, 95\% CI 1.12-5.93) and lack of recognition and respect at work (RR 1.70, 95\% CI 0.98-2.94) showed a significant or almost significant independent relation to sick leave attributed to a back disorder, while exposure to cold did not. Previous experience of back disorders modified the relation between cold and sick leave attributed to a back disorder. The association was not found among those who reported previous experience of recurrent low-back pain (RR $0.86,95 \%$ CI $0.44-1.70$ ), while, for those who did not report previous experience of recurrent low-back pain, sick leave attributed to a back disorder was 4 times more common (RR 4.10, 95\% CI 1.88-8.93) among those who considered their work environment to be cold than among those who did not.

None of the psychosocial factors included in the study modified the relationship between the biomechanical load and sick leave attributed to a back disorder.

\section{Discussion}

The etiology of low-back disorders has been actively investigated for several decades. Over the years it has become increasingly evident that there is no simple mechanism behind the appearance of these disorders. A wide spectrum of workand person-related factors have been found to be associated with low-back pain, but the extent to which these factors precipitate or aggravate symptoms is still unclear (14).

The main criteria for causal inference in epidemiologic studies of risk factors for back pain have been considered to be the strength of the association, whether the association has been established in many settings, whether the association makes sense, whether the cause precedes the effect, and whether an increase or decrease in exposure is associated with a corresponding change in risk (19). Thus an association between some variables need not offer clues to a causal relationship. Diminished trunk muscle strength may, for instance, be a cause of low-back pain, but it may also be an effect of low-back pain. In addition, both diminished trunk muscle strength and low-back pain may be caused by some

Table 5. Age-adjusted rate ratios (RR) and their $95 \%$ confidence intervals $(95 \% \mathrm{Cl})$ between sick leaves and risk factors among workers $(N=189)$.

\begin{tabular}{|c|c|c|c|c|c|c|}
\hline \multirow[t]{3}{*}{ Risk factor } & \multicolumn{6}{|c|}{ Cause of sick leave } \\
\hline & \multicolumn{2}{|c|}{ Back disorder } & \multicolumn{2}{|c|}{$\begin{array}{l}\text { Other musculoskeletal } \\
\text { disorder }\end{array}$} & \multicolumn{2}{|c|}{ Other disorder } \\
\hline & $\mathrm{RR}$ & $95 \% \mathrm{Cl}$ & $\mathrm{RR}$ & $95 \% \mathrm{Cl}$ & $R R$ & $95 \% \mathrm{Cl}$ \\
\hline \multicolumn{7}{|l|}{ Physical environment } \\
\hline $\begin{array}{l}\text { Noise } \\
\text { Cold } \\
\text { Draft } \\
\text { Poor lighting }\end{array}$ & $\begin{array}{l}0.94 \\
1.79 \\
1.67 \\
0.96\end{array}$ & $\begin{array}{l}0.56-1.58 \\
1.07-2.99 \\
0.99-2.81 \\
0.46-1.97\end{array}$ & $\begin{array}{l}0.99 \\
1.21 \\
1.71 \\
1.10\end{array}$ & $\begin{array}{l}0.66-1.49 \\
0.79-1.85 \\
1.13-2.57 \\
0.64-1.89\end{array}$ & $\begin{array}{l}0.62 \\
1.52 \\
1.47 \\
0.88\end{array}$ & $\begin{array}{l}0.45-0.85 \\
1.10-2.09 \\
1.07-2.02 \\
0.56-1.37\end{array}$ \\
\hline Biomechanical load & 3.09 & $1.36-7.03$ & 2.02 & $1.15-3.54$ & 1.67 & $1.09-2.54$ \\
\hline $\begin{array}{l}\text { Lifting, carrying, pushing, pulling } \\
\text { Awkward postures } \\
\text { Harmful standing } \\
\text { Harmful sitting }\end{array}$ & $\begin{array}{l}0.96 \\
1.72 \\
1.40 \\
1.08\end{array}$ & $\begin{array}{l}0.48-1.91 \\
1.01-2.94 \\
0.82-2.39 \\
0.61-1.92\end{array}$ & $\begin{array}{l}2.04 \\
1.97 \\
1.31 \\
1.21\end{array}$ & $\begin{array}{l}1.31-3.16 \\
1.29-3.01 \\
0.86-1.98 \\
0.78-1.89\end{array}$ & $\begin{array}{l}1.32 \\
1.62 \\
1.15 \\
1.07\end{array}$ & $\begin{array}{l}0.91-1.90 \\
1.17-2.25 \\
0.83-1.58 \\
0.75-1.53\end{array}$ \\
\hline \multicolumn{7}{|l|}{ Psychosocial factors } \\
\hline $\begin{array}{l}\text { Few possibilities to affect work conditions } \\
\text { Lack of recognition and respect at work } \\
\text { Job insecurity } \\
\text { Stress }\end{array}$ & $\begin{array}{l}1.05 \\
1.99 \\
1.35 \\
1.10\end{array}$ & $\begin{array}{l}0.59-1.88 \\
1.14-3.46 \\
0.75-2.45 \\
0.62-1.96\end{array}$ & $\begin{array}{l}1.41 \\
1.10 \\
1.21 \\
1.58\end{array}$ & $\begin{array}{l}0.92-2.18 \\
0.60-1.36 \\
0.77-1.91 \\
1.04-2.41\end{array}$ & $\begin{array}{l}1.32 \\
1.11 \\
1.09 \\
0.91\end{array}$ & $\begin{array}{l}0.93-1.86 \\
0.80-1.53 \\
0.77-1.54 \\
0.63-1.32\end{array}$ \\
\hline
\end{tabular}


third factor. In order to shed some light on this "egg" or "chicken" question, we analyzed our data on the basis of the idea of a spiral development process. We not only tried to establish the simultaneous occurrence of "risk factors" and "effects" in a cross-sectional setting, and the predictive value of the "risk factors" in a follow-up design, but also the predictive value of the "effect" in relation to the "risks", in order to determine whether there was some indication of experience of low-back pain predicting future reporting of risk factors.

Our study was carried out among Finnish men employed in the metal industry. The data consisted of responses to a questionnaire distributed twice with a 24-month interval and the rate of sick leave during the intervening period. The questionnaire technique elicits the experiences and the opinions of the population covered by the study, but it does not provide objective measures of potential risk factors, such as exposure to draft or time spent in bent postures. Compared with objective measurements of the physical work environment or biomechanical loads, the questionnaire technique is much cheaper and gives roughly similar results for several variables. Subjective estimates of the effort required in manual materials handling reflect the individual perception of the amount of physical and motivational resources required to meet the demands imposed by the physical task (20). Comparing data obtained by self-administered questionnaires with results from observation studies, Viikari-Juntura et al found lifting and carrying to be reported less often than they were observed, while the adoption of forward bent postures was reported more frequently than it was observed. The correlation between reported and observed loads was better for men without experience of back pain than for men with such experience (21). Those reporting low-back pain have been found to assess lifting tasks as heavier than those not reporting low-back pain (22).

In self-administered questionnaires either open-ended questions or questions with fixed answer alternatives can be used. We chose the latter to facilitate the analysis of the results. In order to gather only essential data, we asked for experience of recurrent back pain rather than back pain as such; we also asked for exposure to harmful risks rather than for risk factors as such. What the respondent considered harmful was up to himself in the same way as, for instance, the decision on what to consider a light, an intermediate, or a heavy load.

Nearly half of the workers did not return the second questionnaire. We are not aware of any systematic bias due to this drop out. Of those who did not answer a second time, $26 \%$ had reported low-back pain in the first questionnaire, while it was reported by $32 \%$ of those who did answer a second time. The difference is not statistically significant.

The data presented in this report were gathered in the initial phase of a 5-year intervention study (15). The intervention activities were started about a year after the first questionnaire. With time, these activities affected some of the risk factors covered in this study, but at the time of the second questionnaire they still had not had much effect. This lack of effect is evident from the fact that both back pain and exposure to risk factors were reported more commonly at the end of the initial 24-month period than at the beginning. Thus the increased awareness of both back pain and exposure to risk factors, introduced by the first questionnaire, seems to have had a stronger effect on the results of the second questionnaire than did the first attempts to improve work conditions.

Biomechanical factors were found to be the most important factors predicting low-back pain. In our opinion, they may well be considered "causal factors" as they precede the appearance of their "effect" and there are known pathophysiological mechanisms relating them to the effect. The importance of prolonged standing as a risk factor appeared more clearly in our study than it had in previous ones. Of the psychosocial factors covered by the questionnaire, stress seems to be a causal factor; it predicts reporting of low-back pain among planners, as well as among workers over 40 years of age.

As suggested by Waddell (23), the biopsychosocial concept can be used as an operational model for low-back disorders. Bongers et al (6) have presented a model of the possible associations of psychosocial factors at work with stress and musculoskeletal symptoms. Their model takes into account the effects of mechanical loads and psychosocial factors at work. Individual characteristics are considered to modify the relations between psychosocial factors and stress symptoms, and between stress symptoms and muscle tone, as well as between acute symptoms and chronic symptoms. We analyzed our data to see whether the psychosocial factors under study modified the effects of the biomechanical factors or vice versa, but no such modification was found. Thus the supposition that stress modifies the relation between mechanical loads and symptoms was not supported by our findings.

Our analysis of the predictive value of reported low-back pain as to future reporting of potential risk factors showed that low-back pain predicted reporting of combined biomechanical loads for both planners and workers. For workers, it also predicted reports of harmful standing and sitting, as well as a lack of possibility to affect work conditions. Possibilities to affect work conditions are probably always limited, but employees become clearly aware of the limitations only when they themselves ask for some measures they consider necessary because of their low-back pain.

The relationship between the experience of low-back pain and sick leave attributed to a back disorder is primarily affected by the strength and duration of the pain, the demands on the back tissues at work, and the economic consequences of being away from work. The last factor was of little or no importance in the groups under study, as the planners receive their ordinary salary and the workers their basic wage 
for the first $1-3$ months (depends on length of employment) on sick leave.

The rare sick leave of planners reporting recurrent lowback pain is probably primarily due to the lack of significant biomechanical loads in their work. In addition, planners have considerable possibilities to arrange their work according to their wishes. However, their low rate of sick leave may also reflect a stricter attitude towards the use of sick-leave benefits. This assumption is in line with the findings of Hemingway et al (13), who also noted a pronounced difference between civil servants of high and low employment grade in the rate of sick leave attributed to back pain. Because the rate of sickness absence was so low among the planners, our data did not allow an analysis of its relation to the risk factors under study.

Among the workers, lack of recognition and respect at work contributed to sick leaves attributed to back disorders. For some reason or other, lack of recognition and respect seem to predict sick leave attributed to back disorders, but not sick leave due to other musculoskeletal disorders. Lack of recognition and respect at work may be due to a variety of reasons, such as below-standard performance, deficient social aptitude, or other factors not directly related to task performance. Leino \& Hänninen (11) reported that poor satisfaction with social relationships at work precedes the appearance of low-back disorders. Bigos et al (24) have paid attention to the psychosocial factors affecting the reporting of back injury in the United States. Using the MMPI questionnaire, as well as another questionnaire originally developed as a measure of the family support system but modified to examine the perceptions of social support at work, they found that lack of support was related to injury reports. Himmelstein et al (25) have drawn attention to the need to avoid employer-employee conflicts in the prevention of prolonged work disability due to upper-extremity disorders. Anger towards the representatives of the employer may also contribute to sick leave attributed to low-back pain. Recently, Burton et al (26) found that sick leave attributed to back pain among police officers was related to complaints about police work. These complaints may include a lack of recognition and respect at work as an important component, but the questionnaire employed did not cover this specific aspect of complaint.

\section{Concluding remarks}

Experience of recurrent low-back pain was preceded by reports of harmful biomechanical loads at work among both planners and workers, by stress among planners and by draft among workers.

The environmental and psychosocial factors under study did not modify the relation between biomechanical loads and the experience of recurrent low-back pain.

Sick leave attributed to a back disorder was preceded by exposure to biomechanical loads at work and by a lack of recognition and respect at work among workers.
Biomechanical loading seems to be the most important occupational factor predicting both recurrent low-back pain and sick leave attributed to back disorders. Lack of recognition and respect at work appear to affect sick leave attributed to a back disorder.

\section{References}

1. Hirsch C. Studies on the mechanism of low back pain. Acta Orthop Scand 1951;20:261-74.

2. Nachemson A. Disc pressure measurement. Spine 1981;6:93-7.

3. Theorell T, Harms-Ringdahl K, Ahlberg-Hultén G, Westin B. Psychosocial job factors and symptoms from the locomotor system a multicausal analysis. Scand J Rehabil Med 1991;23:165-73.

4. Lundberg U, Kadefors R, Melin B, Palmerud G, Hassmén P, Engström M, et al. Psychophysiological stress and EMG activity of the trapezius muscle. Int J Behav Med 1994; 1(4):354_-70.

5. Ursin H, Endresen IM, Svebak S, Tellnes G, Mykletun R. Muscle pain and coping with working life in Norway: a review. Work Stress 1993;7(3):247-58.

6. Bongers PM, de Winter CR, Kompier MAJ, Hildebrandt VH. Psychosocial factors at work and musculoskeletal disease [review]. Scand J Work Environ Health 1993;19:297-312.

7. Johansson JÅ, Rubenowitz S. Arbetstelaterade besvär i rörelsesorganen: psykosociala faktorer och fysisk belasting. Stockholm: Arbetsmiljöfonden, 1994.

8. Toomingas A, Theorell T, Michélsen H, Nordemar R, Stockholm MUSIC I Study Group. Associations between self-rated psychosocial work conditions and musculoskeletal symptoms and signs. Scand J Work Environ Health 1997;23:130-9.

9. Houtman ILD, Bongers PM, Smulders PGW, Kompier MAJ. Psychosocial stressors at work and musculoskeletal problems. Scand J Work Environ Health 1994;20:139 - 45.

10. Riihimäki H, Viikari-Juntura E, Moeta G, Kuha J, Videman T, Tola $S$. Incidence of sciatic pain among men in machine operating, dynamic physical work, and sedentary work - a three year follow-up. Spine 1994;19:138-42.

11. Leino PI, Hänninen V. Psychosocial factors at work in relation to back and limb disorders. Scand J Work Environ Health 1995;21:134-42

12. Manninen $P$, Riihimäki H, Heliövaara $M$. Has musculoskeletal pain become less prevalent. Scand J Rheumatol 1996;25:37-41.

13. Hemingway H, Shipley MJ, Stansfeld S, Marmot M. Sickness absence from back pain, psychosocial work characteristics and employment grade among office workers. Scand J Work Environ Health 1997;23:121-9.

14. Riihimäki H. Low-back pain, its origin and risk indicators [review]. Scand J Work Environ Health 1991;17:81—90.

15. Wickström G, Hyytiäinen K, Laine M, Pentti J, Selonen R. A fiveyear intervention study to reduce low back disorders in the metal industry. Int J Ind Ergon 1993;12:25-33.

16. World Health Organization (WHO). International classification of diseases, 1975 revision. Geneva: WHO, 1977:773 p.

17. SAS Institute Inc. SAS technical report P-200, SAS/STAT software: CALIS and LOGISTIC procedures, release 6.04. Cary (NC): SAS Institute Inc, 1990:236 pp.

18. SAS Institute Inc. SAS technical report P-243, SAS/STAT software: the GENMOD procedure, release 6.09. Cary (NC): SAS Institute Inc, 1993:88 p.

19. Bombardier C, Kerr MS, Shannon HS, Frank JW. A guide to interpreting epidemiologic studies on the etiology of back pain. Spine 
1994;19:2047-56.

20. Gamberale F. Perception of effort in manual materials handling. Scand J Work Environ Health 1990;16 suppl 1:59—66.

21. Viikari-Juntura E, Rauas S, Martikainen R, Kuosma E, Rihimäki H, Takala E-P, et al. Validity of self-reported physical work load in epidemiologic studies on musculo-skeletal disorders. Scand J Work Environ Health 1996;22:251 -9.

22. Wiktorin C, Karlqvist L, Winkel J, Stockholm MUSIC I Study Group. Validity of self-reported exposures to work postures and manual materials handling. Scand J Work Environ Health 1993:19:208-14.

23. Waddell G. A new clinical model for the treatment of low-back pain. Spine 1987;12:632-44.
24. Bigos S, Battié M, Spengler D, Fisher L, Fordyce W, Hansson T et al. A prospective study of work perceptions and psychosocial factors affecting the report of back injury. Spine 1991;16:1 -6.

25. Himmelstein J, Fenerstein M, Stanek E, Koyamatsu K, Pransky G, Morgan W, et al. Work-related upper-extremity disorders and work disability: clinical and psychosocial presentation. J Occup Environ Med 1995;37:1278-86.

26. Burton AK, Tillotson KM, Symonds TL, Burke C, Mathewson T. Occupational risk factors for the first-onset and subsequent course of low back trouble. Spine 1996;21:2612 - 20.

Received for publication: 22 May 1997 